\title{
OPEM
}

www.opem.org

Oriental Pharmacy and Experimental Medicine 2008 8(1), 39-46

DOI 10.3742/OPEM.2008.8.1.039

\section{Study on diuretic activity and electrolytes excretion of methanol extract of Lippia nodiflora (Verbenaceae) in rats}

\author{
Ashok kumar $D^{1, *}$, Senthilkumar GP ${ }^{1}$, Thamil selvan $V^{1}$, Mazumder $\mathrm{UK}^{\mathbf{1}}$, Gupta $^{\mathbf{1}}$ and Ray SK ${ }^{\mathbf{2}}$ \\ ${ }^{1}$ Department of Pharmaceutical Technology, Jadavpur University, Kolkata-700 032, India; ${ }^{2}$ Central Drug \\ Laboratory, 3, Kyd Street, Kolkata, India
}

\begin{abstract}
SUMMARY
In the Indian traditional medicine, Lippia nodiflora (Verbenaceae) whole plant is claimed to possess powerful diuretic activity. However, the diuretic potential of this plant is not yet investigated. The aim of this study was to evaluate the diuretic potential of methanol extract of Lippia nodiflora (MELN) in rats. Control $(0.9 \%$ saline solution, $25 \mathrm{ml} / \mathrm{kg}$, b.w) or urea $(1 \mathrm{~g} / \mathrm{kg} \mathrm{b.w})$ or frusemide $(5 \mathrm{mg} / \mathrm{kg}$ b.w) and different concentrations of MELN (200 and $400 \mathrm{mg} / \mathrm{kg} \mathrm{b.w)}$ were intraperitoneally administered ( $n=6$ per each treatment group) to hydrated rats and their urine output was monitored over a period of $5 \mathrm{~h}$ and $24 \mathrm{~h}$ after drug administration. The diuretic responses with its electrolyte excretion potency of the extract were highly remarkable in comparison with control animals. The extract at doses of 200 and $400 \mathrm{mg} / \mathrm{kg}$ shows a significant increase in volume of urine with increase in $\mathrm{Na}^{+}, \mathrm{Ca}^{2+}$ and $\mathrm{Cl}^{-}$excretion accompanied by the excretion of $\mathrm{K}^{+}$in dose dependent manner. This study suggests that the active component(s) in MELN had similar diuretic effect to that of frusemide. These results validate the traditional use of Lippia nodiflora as a diuretic agent.
\end{abstract}

Keywords: Lippia nodiflora; Methanol extract; Urinary volume; Diuretic activity; Electrolyte excretion.

\section{INTRODUCTION}

Diuretics play an important role in situations of fluid overload, like acute and chronic renal failure, hypercalciurea, cirrhosis of liver and also as an antihypertensive agent. A number of diuretics like mannitol, thiazides, frusemide, and ethacrinic acid are used in practice. Still there is a need for more effective and less toxic diuretic. Many indigenous drugs have been claimed to have diuretic effect in Ayurveda system of medicine but they were not

\footnotetext{
*Correspondence: Ashok kumar D, Department of Pharmaceutical Technology, Jadavpur University, Kolkata-700032, West Bengal, India. Tel: +919433435247; E-mail: ashokkumardurairaj@yahoo.co.in
}

properly investigated. Among the several plants Dolichus biflorus, Tribulus terrestris, Dendrophthoe falcate, Boerhaavia diffusa, Saccharum oficinarum, Butea frondosa, Boerhaavia repens, Boerhaavia rependa, Homonia riparia have shown excellent diuretic activity (Harvey, 1966; Singh and Udupa, 1972; Rani, 1988; Srivastava et al., 1988; Ramachandra, 1989; Singh et al., 1991; Alekutty et al., 1993; Zafar, 1994).

Lippia nodiflora Mich (Verbenaceae) is a creeping perennial herb with small white flowers, a weed of wet ground and grassy pastures (Gamble, 1957; Chopra et al., 1958). The herb is known as poduthalai in Tamil. The plant is distributed throughout India, Ceylon, Baluchistan and Africa. 
The plant is diuretic, aphrodisiac, useful in diseases of heart, good for ulcers and bronchitis, useful in fevers and colds (Kirthikar and Basu, 1975). The herb possesses cooling, diuretic and stoppage of pain knee joints (Wealth of India, 1962; The Useful Plants of India, 1986). The plant made into a poultice used as maturant for boils (Nadkarni, 1954; Chopra et al., 1956). Aqueous extract of leaves of the plant were reported for the anti-inflammatory, analgesic and antipyretic activity in rodents (Caceres et al., 1991; Forestieri et al., 1996) and used for the treatment of gonorrhea (Zamora-Martinez and Nieto de Pascual, 1992). Antimicrobial activity was reported from the herb (Mukherjee, 1991).

There is paucity of data about the pharmacological activities of Lippia nodiflora, which prompted us to pursue this pharmacological evaluation of Lippia nodiflora whole plant to verify the medicinal properties. Therefore, the present study was undertaken to evaluate the diuretic activity of methanol extract of Lippia nodiflora in normal rats.

\section{MATERIAL AND METHODS}

\section{Plant material and extraction}

Lippia nodiflora was collected from Mallasamudram, Namakkal District, Tamilnadu, India. The plant material was taxonomically identified by the H.O.D, Department of Botany, Kuvempu First Grade College, Channapatna, Karnataka, India. A voucher specimen (No DAKJU-04/2005) has been preserved in our laboratory. The whole plant was dried under shade and then powdered with a mechanical grinder and stored in an air tight container, The dried powdered material was defatted with petroleum ether $\left(60-80^{\circ} \mathrm{C}\right)$ followed by the extraction with methanol in a soxhlet apparatus. Phytochemical screening of the extract revealed the presence of flavonoids, saponins, triterpenes, phenolic compounds (tannins) and steroids (Kokate, 1997). Methanol extract of Lippia nodiflora (MELN) was dissolved in distilled water prior to administration for the pharmacological studies.

\begin{abstract}
Animals
Male Wister albino rats (150 - $180 \mathrm{~g}$ ) were purchased from Indian Institute of Chemical Biology, Kolkata, India. After screening, the animals were taken and kept in identical condition (12 h light: $12 \mathrm{~h}$ dark cycle) at $25 \pm 0.5^{\circ} \mathrm{C}$ in the animal unit, Department of Pharmaceutical Technology, Jadavpur University, Kolkata atleast 7 days prior to pharmacological studies, with free access to pellet diet (Hindustan Lever Limited, Mumbai) and water ad libitum.
\end{abstract}

\section{Chemicals and drugs}

Petroleum ether $\left(60-80^{\circ} \mathrm{C}\right)$ from E. Merck Limited, Mumbai, methanol and urea from Sisco Research Laboratories Pvt Ltd, Mumbai, frusemide (Lasix) was obtained from Aventis pharma limited, Thane. All other chemicals used were of reagent grade.

\section{Acute toxicity study}

Acute toxicity study was performed as per OECD423 guidelines (acute toxic classic method), (Ecobichon, 1997). Wister rats of either sex selected by random sampling technique were used for acute toxicity study. The animals were kept fasting for overnight providing only with water. The extracts were administered orally at the dose level of $5 \mathrm{mg} / \mathrm{kg}$ body weight and observed for 14 days. If mortality was observed in 2 out of 3 animals, then the dose assigned as a toxic dose. If mortality was not observed, the procedure was repeated for higher doses such as 50,100, 200, 400, 800, 1,600 and $2,000 \mathrm{mg} / \mathrm{kg}$ body weight. On the basis of $\mathrm{LD}_{50}$, two doses were selected for detailed study.

\section{Screening of diuretic activity}

The method of Lipschitz et al. (1943) was employed for the assessment of diuretic activity, male albino rats weighing 150 - $180 \mathrm{~g}$ were selected, and the tail base was pressed to empty the bladder of remaining urine. The test animals were divided into five groups, containing six rats in each group. All the animals received normal saline $(25 \mathrm{ml} / \mathrm{kg}$, b.w) orally prior to start of the experiment. Group I 
served as a control and was fed only with normal saline. Group II received urea $(1 \mathrm{~g} / \mathrm{kg})$ as positive control and frusemide $(5 \mathrm{mg} / \mathrm{kg}$ ) as reference standard diuretic. Group IV and V received the test materials, (MELN) at doses of 200 and $400 \mathrm{mg} / \mathrm{kg}$, b.w respectively. Immediately after dosing the rats were placed in metabolic cages and kept at room temperature of $25 \pm 0.5^{\circ} \mathrm{C}$. During this period, no food and water was made available to them. The urinary output of each group was recorded at $5^{\text {th }} \mathrm{h}$ and $24^{\text {th }} \mathrm{h}$ from the graduated urine chamber of metabolic cage. Animals were taken out of the cages and urine samples, which are collected from metabolic cage, were analysed for $\mathrm{Na}^{+}, \mathrm{K}^{+}, \mathrm{Ca}^{2+}$ and $\mathrm{Cl}^{-}$in mMol/1 (Mukherjee et al., 1996; Murugesan et al., 2000; Mamun et al., 2003). Urine samples were analysed for $\mathrm{Na}^{+}, \mathrm{K}^{+}$and $\mathrm{Ca}^{2+}$ concentration by a flame photometer (Chemito 1,020) while $\mathrm{Cl}^{-}$concentration was determined titrimetrically (Indian pharmacopoeia, 1996). The $\mathrm{pH}$ values were measured with a $\mathrm{pH}$ meter (Mettler Toledo, Seven Easy) (Sheth et al., 1972). The instrument was calibrated with standard solutions containing different concentration of $\mathrm{Na}^{+}, \mathrm{K}^{+}$and $\mathrm{Ca}^{2+}$ (Muneer et al., 2003).

The volume of urine excreted at $5 \mathrm{~h}$ and $24 \mathrm{~h}$ in each group of animals has been expressed as percent of liquid administered (Gujral et al., 1955). This percentage gives a measure of "urinary excretion" (U.E) - independent of group weight, thus

Urinary excretion $=\frac{\text { Total urinary output }}{\text { Total liquid administered }}$ $\times 100$

The ratio, urinary excretion in test group: urinary excretion in control group has been used for the measure of diuretic action for the treated groups.

Diuretic action

$$
=\frac{\text { Urinary excretion in test group }}{\text { Urinary excretion in control group }}
$$

The relative diuretic potency can be determined by Van Armar (1954). To obtain the diuretic activity, the test groups (MELN) were compared with reference standard diuretic, Urea.

Diuretic activity $=\frac{\text { Diuretic action of extract }}{\text { Diuretic action of Urea }}$

The sum of $\mathrm{Na}^{+}$and $\mathrm{Cl}^{-}$excretion was estimated for saliuretic activity. The ratio $\mathrm{Na}^{+} / \mathrm{K}^{+}$was estimated as a natriuretic activity. The ratio $\mathrm{Cl}^{-} / \mathrm{Na}^{+}+\mathrm{K}^{+}$(ion quotient) was derived to estimate carbonic anhydrase inhibition (Somova et al., 2003).

\section{Statistical analysis}

Results are mean \pm S.E.M. Statistical analysis of control and test data was determined by ANOVA (SPSS computer software) followed by one-way analyses of variance were used for different doses within a group. $P$ value of 0.001 was considered statistically significant.

\section{RESULTS}

The hot extraction of coarse powder (350 g) of Lippia nodiflora was carried out with petroleum ether and methanol, which yielded $2.91 \%$ and $21.42 \%$, respectively. The phytochemical analysis showed the presence of flavonoids, triterpenes, phenolic compounds (tannins) and steroids.

\section{Acute toxicity study}

MELN did not cause any mortality up to 2,000 $\mathrm{mg} / \mathrm{kg}$ and were considered as safe (X-unclassified) (OECD, 1996).

\section{Effects on urine volume and diuretic activity}

Table 1 and 2, showed that, the cumulative urine volume was measured at $5^{\text {th }} \mathrm{h}$ and again after $24^{\text {th }} \mathrm{h}$ of control ( $0.66 \pm 0.006$ and $2.24 \pm 0.006)$, urea $(0.83$ \pm 0.02 and $2.50 \pm 0.01)$, frusemide $(2.13 \pm 0.01$ and $4.33 \pm 0.01)$ and MELN at $200 \mathrm{mg}(0.97 \pm 0.04$ and $2.57 \pm 0.13)$ and $400 \mathrm{mg} / \mathrm{kg}(1.83 \pm 0.04$ and $3.98 \pm$ 0.13). The urine volume was significantly $(P<$ 
Table 1. MELN on urine volume and diuretic activity at $5^{\text {th }} \mathrm{h}$ in rats

\begin{tabular}{lccccc}
\hline Groups & $\begin{array}{c}\text { Urine volume } \\
(\mathrm{ml})\end{array}$ & $\begin{array}{c}\text { Urinary } \\
\text { Excretion } \\
\left(\mathrm{V}_{0} / \mathrm{V}_{1}\right) \times 100\end{array}$ & $\begin{array}{c}\text { Diuretic } \\
\text { Action } \\
\left(\mathrm{UE}_{\mathrm{t}} / \mathrm{UE}_{\mathrm{c}}\right)\end{array}$ & $\begin{array}{c}\text { Diuretic Activity } \\
\left(\mathrm{DA}_{\mathrm{t}} / \mathrm{DA}_{\mathrm{u}}\right)\end{array}$ & $\begin{array}{c}\mathrm{pH} \\
(1 \% \mathrm{solution})\end{array}$ \\
\hline Control $(25 \mathrm{ml}$ of $0.9 \% \mathrm{Nacl} / \mathrm{kg})$ & $0.66 \pm 0.01$ & 18.11 & - & - & $7.31 \pm 0.02$ \\
Urea $(1 \mathrm{~g} / \mathrm{kg})$ & $0.83 \pm 0.02^{\mathrm{a}, \mathrm{c}^{*}}$ & 21.56 & 1.19 & - & $8.62 \pm 0.01^{\mathrm{a}^{*}, \mathrm{c}^{*}}$ \\
Frusemide $(5 \mathrm{mg} / \mathrm{kg})$ & $2.13 \pm 0.01^{\mathrm{a}^{*}, \mathrm{~b}^{*}}$ & 54.34 & 3.00 & 2.52 & $9.25 \pm 0.02^{\mathrm{a}^{*}, \mathrm{~b}^{*}}$ \\
MELN $(200 \mathrm{mg} / \mathrm{kg})$ & $0.97 \pm 0.04^{\mathrm{a}^{*}, \mathrm{~b}, \mathrm{c}^{*}}$ & 25.53 & 1.41 & 1.18 & $8.57 \pm 0.03^{\mathrm{a}^{*}, \mathrm{c}^{*}}$ \\
MELN $(400 \mathrm{mg} / \mathrm{kg})$ & $1.83 \pm 0.04^{\mathrm{a}^{*}, \mathrm{~b}^{*} \mathrm{c}^{*}}$ & 48.80 & 2.69 & 2.26 & $9.02 \pm 0.06^{\mathrm{a}^{*}, \mathrm{~b}^{*}, \mathrm{c}}$ \\
\hline
\end{tabular}

Values are expressed as mean \pm S.E.M. (Number of animals, $\mathrm{n}=6$ ). $\mathrm{V}_{0}$ : Total urinary output; $\mathrm{V}_{1}$ : Total fluid input; $\mathrm{UE}_{\mathrm{t}}$ : Urinary excretion in test group; $\mathrm{UE}_{\mathrm{c}}$ : Urinary e.xcretion in control group; $\mathrm{DA}_{\mathrm{t}}$ : Diuretic action of the test sample; $\mathrm{DA}_{\mathrm{u}}$ : Diuretic action of the Urea. a and $\mathrm{a}^{*}$ indicates $P<0.05$ and $P<0.001 \mathrm{vs}$. Control, $\mathrm{b}$ and $\mathrm{b}^{*}$ indicates $P<$ 0.05 and $P<0.001$ vs. Urea, $c$ and $c^{*}$ indicates $P<0.05$ and $P<0.001$ vs. Frusemide.

Table 2. MELN on urine volume and diuretic activity at $24^{\text {th }} \mathrm{h}$ in rats

\begin{tabular}{|c|c|c|c|c|c|}
\hline Groups & $\begin{array}{l}\text { Urine volume } \\
(\mathrm{ml})\end{array}$ & $\begin{array}{l}\text { Urinary Excreti } \\
\left(\mathrm{V}_{0} / \mathrm{V}_{1}\right) \times 100\end{array}$ & $\begin{array}{c}\text { Diuretic Action } \\
\left(\mathrm{UE}_{\mathrm{t}} / \mathrm{UE}_{\mathrm{c}}\right)\end{array}$ & $\begin{array}{l}\text { Diuretic Activity } \\
\left(\mathrm{DA}_{\mathrm{t}} / \mathrm{DA}_{\mathrm{u}}\right)\end{array}$ & $\begin{array}{c}\mathrm{pH} \\
\text { (1\% solution) }\end{array}$ \\
\hline $\begin{array}{l}\text { Control } \\
(25 \mathrm{ml} \text { of } 0.9 \% \mathrm{Nacl} / \mathrm{kg})\end{array}$ & $2.24 \pm 0.01$ & 60.27 & - & - & $7.25 \pm 0.01$ \\
\hline Urea $(1 \mathrm{~g} / \mathrm{kg})$ & $2.50 \pm 0.01^{\mathrm{c}^{*}}$ & 64.94 & 1.08 & - & $8.54 \pm 0.01^{\mathrm{a}^{*}, \mathrm{c}^{*}}$ \\
\hline Frusemide $(5 \mathrm{mg} / \mathrm{kg})$ & $4.33 \pm 0.01^{\mathrm{a}^{*}, \mathrm{~b}^{*}}$ & 110.46 & 1.83 & 1.69 & $8.94 \pm 0.02^{\mathrm{a}^{*}, \mathrm{~b}^{*}}$ \\
\hline MELN (200 mg/kg) & $2.57 \pm 0.13^{\mathrm{c}^{*}}$ & 67.63 & 1.12 & 1.04 & $8.46 \pm 0.02^{\mathrm{a}^{*}, \mathrm{c}^{*}}$ \\
\hline MELN (400 mg/kg) & $3.98 \pm 0.13^{\mathrm{a}^{*}, \mathrm{~b}^{*}, \mathrm{c}}$ & 106.13 & 1.76 & 1.63 & $8.81 \pm 0.02^{\mathrm{a}^{*}, \mathrm{~b}^{*}, \mathrm{c}}$ \\
\hline
\end{tabular}

Values are expressed as mean \pm S.E.M. (Number of animals, $n=6$ ). $\mathrm{V}_{0}$ : Total urinary output; $\mathrm{V}_{1}$ : Total fluid input; $\mathrm{UE}_{\mathrm{t}}$ : Urinary excretion in test group; $\mathrm{UE}_{\mathrm{c}}$ : Urinary excretion in control group; $\mathrm{DA}_{\mathrm{t}}$ : Diuretic action of the test sample; $\mathrm{DA}_{\mathrm{u}}$ : Diuretic action of the Urea. a and $\mathrm{a}^{*}$ indicates $P<0.05$ and $P<0.001 \mathrm{vs}$. Control, $\mathrm{b}$ and $\mathrm{b}^{*}$ indicates $P<$ 0.05 and $P<0.001$ vs. Urea, $\mathrm{c}$ and $\mathrm{c}^{*}$ indicates $P<0.05$ and $P<0.001$ vs. Frusemide.

0.001) increased in MELN as well as frusemide treated animals comparision with saline treated rats. The MELN at both doses showed dose dependent increase in urine volume in rats. On the basis of urine volume in rats, diuretic activity (Lipschitz value) of standard drug frusemide and MELN at $200 \mathrm{mg}$ and $400 \mathrm{mg} / \mathrm{kg}$ calculated were $2.52,1.18$ and 2.26 at $5 \mathrm{~h}$ and 1.69, 1.04 and 1.63 at $24 \mathrm{~h}$, which indicates the extracts acts in dose dependent manner.

\section{Effects on electrolytes excretion and $\mathrm{pH}$}

The diuretic responses with its electrolyte excretion potency of the extract (MELN) are highly significant in comparison with control animals. MELN increased significantly $(P<0.001)$ the level of $\mathrm{Na}^{+}, \mathrm{Ca}^{2+}$ and $\mathrm{Cl}^{-}$excretion accompanied by the excretion of $\mathrm{K}^{+}$at the dose of $200 \mathrm{mg}$ and $400 \mathrm{mg} / \mathrm{kg}$ from that of control in dose dependent manner (Table 3 and 4). The urine $\mathrm{pH}$ ( $1 \%$ solution) of control animals, $7.31 \pm 0.02$ and $7.25 \pm 0.01$ at $5 \mathrm{~h}$ and $24 \mathrm{~h}$. Urea was $8.62 \pm 0.01$ and $8.54 \pm 0.01$ after $5 \mathrm{~h}$ and $24 \mathrm{~h}$. Frusemide increased the urine $\mathrm{pH} 9.25 \pm 0.02$ and $8.94 \pm 0.02$ at $5 \mathrm{~h}$ and $24 \mathrm{~h}$. MELN at the dose level of 200 and $400 \mathrm{mg} / \mathrm{kg}$, b.w showed $8.57 \pm 0.03,9.02$ \pm 0.008 and $8.34 \pm 001,8.63 \pm 0.01$ after $5 \mathrm{~h}$ and $24 \mathrm{~h}$, thus making the urine more alkaline.

Effects on natriuretic, saliuretic and carbonic anhydrase inhibition

From the electrolyte excretion of $\mathrm{Na}^{+}, \mathrm{K}^{+}$and $\mathrm{Cl}^{-}$of MELN at both dose levels (200 $\mathrm{mg}$ and $400 \mathrm{mg} / \mathrm{kg}$ ), the natriuretic $\left(\mathrm{Na}^{+} / \mathrm{K}^{+}\right)$, saliuretic $\left(\mathrm{Na}^{+}\right.$and $\left.\mathrm{Cl}^{-}\right)$ activity and carbonic anhydrase inhibition $\left(\mathrm{Cl}^{-} / \mathrm{Na}^{+}+\right.$ 
Table 3. MELN on electrolytes excretion, saliuretic and natriuretic activity at $5^{\text {th }} \mathrm{h}$ in rat

\begin{tabular}{|c|c|c|c|c|c|c|c|}
\hline \multirow{2}{*}{ Groups } & \multicolumn{4}{|c|}{ Electrolytes excretion in $\mathrm{mMol} / 1$} & \multirow{2}{*}{$\mathrm{Na}^{+}+\mathrm{Cl}^{-}$} & \multirow{2}{*}{$\mathrm{Na}^{+} / \mathrm{K}^{+}$} & \multirow{2}{*}{$\underset{\mathrm{K}^{+}}{\mathrm{Cl}^{-} / \mathrm{Na}^{+}+}$} \\
\hline & $\mathrm{Na}^{+}$ & $\mathrm{K}^{+}$ & $\mathrm{Ca}^{++}$ & $\mathrm{Cl}^{-}$ & & & \\
\hline \multirow{2}{*}{$\begin{array}{c}\text { Control }(25 \mathrm{ml} \text { of } \\
0.9 \% \mathrm{Nacl} / \mathrm{kg}) \\
\end{array}$} & 133.43 & 55.51 & 59.66 & 105.33 & 238.76 & 2.40 & 0.5575 \\
\hline & \pm 0.04 & \pm 1.15 & \pm 0.34 & \pm 0.66 & \pm 0.70 & \pm 0.05 & \pm 0.001 \\
\hline \multirow{2}{*}{ Urea $(1 \mathrm{~g} / \mathrm{kg})$} & 150.26 & 67.50 & 68.79 & 146.66 & 296.93 & 2.23 & 0.6740 \\
\hline & $\pm 3.08^{\mathrm{a}, c^{*}}$ & $\pm 2.82^{\mathrm{a}^{*}, c^{*}}$ & $\pm 0.54^{\mathrm{a}, \mathrm{c}}$ & $\pm 1.76^{\mathrm{a}^{*} \mathrm{c}^{*}}$ & $\pm 4.84^{\mathrm{a}^{*} \mathcal{C}^{*}}$ & $\pm 0.05^{\mathrm{ac}}$ & $\pm 0.010^{\mathrm{a}^{*}, \mathrm{~b}^{*}, c^{*}}$ \\
\hline $\begin{array}{l}\text { Frusemide } \\
\text { (5 mg/kg) }\end{array}$ & $\begin{array}{c}216.76 \\
\pm 3.78^{\mathrm{a}^{*}, b^{*}}\end{array}$ & $\begin{aligned} & 89.98 \\
\pm & 0.93^{\alpha^{*}, b^{*}}\end{aligned}$ & $\begin{aligned} & 78.12 \\
\pm & 3.24^{\mathrm{a}^{*}, \mathrm{~b}}\end{aligned}$ & $\begin{array}{c}176.33 \\
\pm 3.17^{*, b^{*}}\end{array}$ & $\begin{array}{c}393.09 \\
\pm 6.95^{{ }^{*}, b^{*}}\end{array}$ & $\begin{array}{r}2.40 \\
\pm 0.01^{\mathrm{b}}\end{array}$ & $\begin{array}{c}0.5748 \\
\pm 0.001^{b^{*}}\end{array}$ \\
\hline \multirow{2}{*}{$\begin{array}{c}\text { MELN } \\
(200 \mathrm{mg} / \mathrm{kg})\end{array}$} & 175.79 & 72.90 & 70.50 & 151.33 & 327.13 & 2.41 & 0.6084 \\
\hline & $\pm 1.90^{\mathrm{a}^{*}, b^{*}, c^{*}}$ & $\pm 0.84^{\mathrm{a}^{*}, c^{*}}$ & $\pm 0.38^{\mathrm{ac}}$ & $\pm 2.40^{\mathrm{a}^{*} \kappa^{*}}$ & $\pm 4.30^{*, \mathrm{k}, \mathrm{c}^{*}}$ & $\pm 0.01^{\mathrm{b}}$ & $\pm 0.003^{2^{*}, b^{*}, c}$ \\
\hline \multirow{2}{*}{$\begin{array}{c}\text { MELN } \\
(400 \mathrm{mg} / \mathrm{kg})\end{array}$} & 211.30 & 87.18 & 75.83 & 160.66 & 371.97 & 2.42 & 0.5383 \\
\hline & $\pm 2.65^{\mathrm{a}^{*}, \mathrm{~b}^{*}}$ & $\pm 0.59^{\mathrm{a}^{*}, b^{*}}$ & $\pm 0.72^{\mathrm{a}^{*}, \mathrm{~b}}$ & $\pm 1.76^{\mathrm{a}^{*}, \mathrm{~b}, \mathrm{c}}$ & $\pm 4.27^{\mathrm{a}^{*}, b^{*}, \mathcal{C}}$ & $\pm 0.01^{\mathrm{b}}$ & $\pm 0.003^{b^{*}, \mathrm{c}}$ \\
\hline
\end{tabular}

Values are expressed as mean \pm S.E.M. (Number of animals, $\mathrm{n}=6$ ). a and a indicates $P<0.05$ and $P<0.001$ vs. Control, $\mathrm{b}$ and $\mathrm{b}^{*}$ indicates $P<0.05$ and $P<0.001$ vs. Urea, $\mathrm{c}$ and $\mathrm{c}^{*}$ indicates $P<0.05$ and $P<0.001$ vs. Frusemide

Table 4. MELN on electrolytes excretion, saliuretic and natriuretic activity at $24^{\text {th }} \mathrm{h}$ in rats

\begin{tabular}{cccccccc}
\hline \multirow{2}{*}{ Groups } & \multicolumn{3}{c}{ Electrolytes excretion in mMol/1 } & \multirow{2}{*}{$\mathrm{Na}^{+}+\mathrm{Cl}^{-}$} & \multirow{2}{*}{$\mathrm{Na}^{+} / \mathrm{K}^{+}$} & $\mathrm{Cl}^{-} / \mathrm{Na}^{+}+$ \\
\cline { 2 - 5 } & $\mathrm{Na}^{+}$ & $\mathrm{K}^{+}$ & $\mathrm{Ca}^{++}$ & $\mathrm{Cl}^{-}$ & & & \\
\hline Control $(25 \mathrm{ml}$ of & 146.57 & 88.58 & 96.71 & 188.00 & 334.57 & 1.65 & 0.7995 \\
$0.9 \% \mathrm{Nacl} / \mathrm{kg})$ & \pm 0.05 & \pm 1.20 & \pm 1.02 & \pm 1.15 & \pm 1.65 & \pm 0.01 & \pm 0.001 \\
\hline Urea $(1 \mathrm{~g} / \mathrm{kg})$ & 168.22 & 101.79 & 123.93 & 218.00 & 386.22 & 1.65 & 0.8074 \\
& $\pm 1.31^{\mathrm{a}^{*}}$ & $\pm 1.64^{\mathrm{a}^{*}, \mathrm{c}^{*}}$ & $\pm 0.83^{\mathrm{a}^{*}, \mathrm{c}^{*}}$ & $\pm 1.73^{\mathrm{a}^{*}, \mathrm{c}^{*}}$ & $\pm 3.04^{\mathrm{a}^{*}, \mathrm{c}^{*}}$ & $\pm 0.03^{\mathrm{c}}$ & $\pm 0.007^{\mathrm{c}^{*}}$ \\
\hline Frusemide & 170.44 & 110.51 & 140.47 & 242.00 & 412.44 & 1.54 & 0.8614 \\
(5 mg/kg) & $\pm 1.21^{\mathrm{a}^{*}}$ & $\pm 1.28^{\mathrm{a}^{*}, \mathrm{~b}^{*}}$ & $\pm 1.02^{\mathrm{a}^{*}, \mathrm{~b}^{*}}$ & $\pm 1.15^{\mathrm{a}^{*}, \mathrm{~b}^{*}}$ & $\pm 2.37^{\mathrm{a}^{*}, \mathrm{~b}^{*}}$ & $\pm 0.007^{\mathrm{a}^{*}, \mathrm{~b}^{*}}$ & $\pm 0.003^{\mathrm{a}^{*}, \mathrm{~b}^{*}}$ \\
\hline MELN & 163.19 & 103.76 & 121.50 & 221.33 & 384.52 & 1.57 & 0.8291 \\
$(200 \mathrm{mg} / \mathrm{kg})$ & $\pm 0.76^{\mathrm{a}^{*}, \mathrm{~b}, \mathrm{c}}$ & $\pm 0.36^{\mathrm{a}^{*}, \mathrm{c}}$ & $\pm 0.66^{\mathrm{a}^{*}, \mathrm{c}^{*}}$ & $\pm 1.76^{\mathrm{a}^{*}, \mathrm{c}^{*}}$ & $\pm 2.41^{\mathrm{a}^{*}, \mathrm{c}^{*}}$ & $\pm 0.01^{\mathrm{a}^{*}}$ & $\pm 0.004^{\mathrm{a}^{*}, \mathrm{c}^{*}}$ \\
\hline MELN & 166.23 & 108.97 & 136.91 & 236.66 & 402.90 & 1.52 & 0.8599 \\
$(400 \mathrm{mg} / \mathrm{kg})$ & $\pm 0.80^{\mathrm{a}^{*}, \mathrm{c}^{*}}$ & $\pm 0.39^{\mathrm{a}^{*}, \mathrm{~b}}$ & $\pm 0.50^{\mathrm{a}^{*}, \mathrm{~b}^{*}, \mathrm{c}}$ & $\pm 2.90^{\mathrm{a}^{*}, \mathrm{~b}^{*}}$ & $\pm 3.61^{\mathrm{a}^{*}, \mathrm{~b}}$ & $\pm 0.002^{\mathrm{a}^{*}, \mathrm{~b}^{*}}$ & $\pm 0.007^{\mathrm{a}^{*}, \mathrm{~b}^{*}}$ \\
\hline
\end{tabular}

Values are expressed as mean \pm S.E.M. (Number of animals, $\mathrm{n}=6$ ). a and $\mathrm{a}^{*}$ indicates $P<0.05$ and $P<0.001$ vs. Control, $\mathrm{b}$ and $\mathrm{b}^{*}$ indicates $P<0.05$ and $P<0.001 \mathrm{vs.}$. Urea, $\mathrm{c}$ and $\mathrm{c}^{*}$ indicates $P<0.05$ and $P<0.001$ vs. Frusemide.

$\mathrm{K}^{+}$) were estimated and compared with standard diuretics, urea and frusemide. No carbonic anhydrase inhibition was detected (Table 3 and 4 ) (Somova et al., 2003). The natriuretic ratio was 2.41, 2.42 and $1.57,1.52$ at the doses of 200 and $400 \mathrm{mg} /$ $\mathrm{kg}$ of MELN compared with 2.40 and 1.54 of frusemide at $5 \mathrm{~h}$ and $24 \mathrm{~h}$ respectively. The saliuretic effect was 327.13, 371.97 and 384.52, 402.90 of 200 and $400 \mathrm{mg} / \mathrm{kg}$ comparable with 393.09 and 412.44 of frusemide at $5 \mathrm{~h}$ and $24 \mathrm{~h}$ respectively.

\section{DISCUSSION}

Diuretics are drugs that increase the rate of urine flow and sodium excretion and are used to adjust the volume and/or composition of body fluids in a variety of clinical situations, including hypertension, heart failure, nephritic syndrome and cirrhosis. Loop diuretics such as frusemide can increase the urinary flow rate; also they are strongly saliuretic in as much as they increase urinary sodium and chloride excretion (Jackson, 2001) that is why in this study frusemide was used as standard drug. Frusemide used in this experiment belongs to the loop or high ceiling diuretics, which act by inhibiting $\mathrm{Na}^{+} / \mathrm{K}^{+} / 2 \mathrm{Cl}^{-}$cotransport of the luminal membrane in the ascending limb of the loop of Henle and have the highest efficacy in mobilizing 
$\mathrm{Na}^{+}$and $\mathrm{Cl}^{-}$from the body (Das et al., 2005). On the other side, the herbal diuretics produce very little acute toxicity and in general they can be considered as mild and good drugs, in comparison to other diuretics used now a day in therapeutic.

The most important thing is that a large number of these plants are rich in potassium, which would not lead to potassium depletion (Horisberger and Giebisch, 1987). Thirty to seventy percent of the $\mathrm{K}^{+}$ filtered by the glomerules is known to be reabsorbed by the proximal convoluted tubule (Stanton and Giebisch, 1992) by a combination of three processes: active transport, paracellular diffusion and solvent drag (Wilson et al., 1997). It was reported that an increment of the urine output in rats might result from high potassium content in the plant extract (Nilveses et al., 1989). The increased $\mathrm{Na}^{+}$concentration that reaches the distal tubule results increased loss of $\mathrm{K}^{+}$. There is an increase in the excretion of $\mathrm{Ca}^{2+}$ (Rang et al., 2003).

Diuretic has two separate connotations, increase in urine volume and net loss of solute (i.e. electrolytes) and water (i.e. saliuretic effect) (De Stevens, 1963; Jackson, 1996). These two processes are involve in the suppression of renal tubular absorption of electrolytes, water and low molecular weight organic compounds into the blood stream, and as a consequence, promoting the formation of urine (De Stevens, 1963; Milton et al., 1970).

The research work was performed on the basis of its folkloric use as a diuretic. From this work, Lippia nodiflora induced an increment in the urine output and in the electrolyte excretion at both doses of the extract at $5^{\text {th }} \mathrm{h}$ and $24^{\text {th }} \mathrm{h}$ in normal rats. In the $5^{\text {th }} \mathrm{h}$ and $24^{\text {th }} \mathrm{h}$, the MELN extracts showed change in urine output at both dose levels tested $(200$ and $400 \mathrm{mg} / \mathrm{kg})$, the diuretic effect of the methanol extracts was significant at $5 \mathrm{~h}$ and $24 \mathrm{~h}$. However, there was moderately delayed effect at $24^{\text {th }} \mathrm{h}$, even though, the diuretic activity at $24^{\text {th }} \mathrm{h}$ at both doses was significant. It showed the extracts act in dose dependent manner. These results reveal that the methanol extract of Lippia nodiflora is more potent diuretic; the water excretion is higher in the presence of this extract.

It was noted that MELN treatment caused increase in both water and electrolytes excretion qualitatively similar to frusemide, which is known by its potential saliuretic and diuretic effects (Leuschner, 1995). The extract significantly increased the volume of urine with considerable $\mathrm{Na}^{+}$and $\mathrm{Cl}^{-}$load, which was comparable to that of urea and frusemide.

MELN increased significantly urine flow rate and maintain the alkaline $\mathrm{pH}$ as compare with control and more/less similar to frusemide. It is possible that MELN extract exerted its diuretic activity by inhibiting tubular reabsorbtion of water and accompanying anions, as such action has been hypothesized for some plants (Pantoja et al., 1991; Bevevino et al., 1994). As it was emphasizied, diuretic effect of MELN could be due to active phytoconstituents such as flavonoids, saponins and terpenoids (Rizvi et al., 1980; Sood et al., 1985; Chodera et al., 1991). The preliminary phytochemical analysis revealed that these compounds mainly present in the MELN.

In the toxicological evaluation, this plant did not exhibit any toxic effects up to $2,000 \mathrm{mg} / \mathrm{kg}$, b.w. From the experiment, Lippia nodiflora can be considered as nontoxic, because there is no mortality up to $2,000 \mathrm{mg} / \mathrm{kg}$.

In conclusion, the present results demonstrate that Lippia nodiflora (Verbenaceae) induces significant effects on urinary excretion of water and electrolytes. It shows that the active phytoconstituents in MELN had similar diuretic spectrum to that of frusemide. The further work is in progress to find out the active principles responsible for diuretic activity.

\section{ACKNOWLEDGEMENTS}

One of the authors ASHOKKUMAR.D is thankful to All India Council for Technical Education, New Delhi, India for providing financial support for this work. 


\section{REFERENCES}

Al-Ali M, Wahbi S, Twaij H, Al-Badr A. (2003) Tribulus terrestris: Preliminary study of its diuretic and contractile effects and comparision with Zea mays. J. Ethnopharmacol. 85, 257-260.

Alekutty NA, Srinivasan KK, Gundu Rao P, Udupa AC, Keshavamurthy KR. (1993) Diuretic and antilithiatic activity of Dendrophthoe falcate. Fitoterapia 64, 325-331.

Bevevino LH, Vieira FSA, Cassola AC, Sanioto SML. (1994) Effect of crude extract of roots of Bredemeyera floribunda Willd. J. Ethnopharmacol. 43, 197-201.

Caceres A, Fletes L, Aquilar L, Ramirez O, Figueroa L, Taracena AM, Samaya B. (1993) Plants used in Guatemala for the treatment of gastrointestinal disorders. Confirmation of activity against enterobacteria of 16 plants. J. Ethnopharmacol. 38, 31-38.

Chodera A, Dabrowska K, Sloderbach A, Skrzypczak L, Budzianowski J. (1991) Effect of flavanoid fractions of Solidago virgaurea L. on diuresis and levels of electrolytes. Acta. Pol. Pharm. 48, 35-37.

Chopra RN, Nayar SL, Chopra IC. (1956) Glossary of Indian Medicinal Plants, pp. 155 C.S.I.R, New Delhi.

Chopra RN, Chopra IC, Handa KL, Kapur LD. (1958) Indigenous Drugs of India, Second Edition, pp. 598 U.N.Dhur \& Sons Private Limited, Calcutta.

Das AK, Shahid IZ, Choudhuri MSK, Shilpi JA, Firoj Ahmed. (2005) Anti-inflammatory, antinociceptive and diuretic activities of Amoora Cucullata Roxb. Orient. Pharm. Exp. Med. 5, 37-42.

Gamble JS. (1957) Flora of the Presidency of Madras, Vol II, pp. 762 Botanical survey of India, Calcutta.

Ecobichon DJ. (1997) The basis of toxicity testing, pp. 43-86 CRC Press, New York.

Forestieri AM, Monforte MT, Ragusa S, Trovato A, Iauk L. (1996) Antiinflammatory, analgesic and antipyretic activity in rodents of plant extracts used in African medicine. Phytother. Res. 10, 100-106.

De Stevens G. (1963) Diuretics: In: Chemistry and Pharmacology, $1^{\text {st }}$ ed. p.2-7 and 52-58, Academic Press, New York.

Gujral ML, Saxena PN, Misra SS. (1955) An experimental study of the comparative activity of indigenous diuretics. J. Indian Med. Assoc. 25, 49-51.

Harvey SK. (1966) A preliminary experimental study of the diuretic activity of some indigenous drug.
Indian J. Med. Res. 54, 774-778.

Horisberger JD, Giebisch G. (1987) Potassium sparing diuretics. Ren. Physiol. 10, 198-220.

Indian Pharmacopoeia. (1996) Publications and Information Directorate, pp. 689 CSIR, New Delhi.

Jackson EK. (1996) Drugs affecting renal and cardiovascular function. In: Goodman and Gilman's The Pharmacological Basis of Therapeutics edited by Hardman JG, Gilman AG, Limbird LE $9^{\text {th }}$ ed. p. 685713 McGraw-Hill, New York.

Jackson EK. (2001) Diuretics. In: Goodman \& Gilman's The Pharmacological Basis of Therapeutics edited by Hardman JG, Limbird LE, Goodman GA p. 755788 McGraw-Hill, New York.

Kirthikar KR and Basu BD. (1975) Indian Medicinal Plants, Vol III, 1915-1917 pp. 1915-1917 Bishen Mahendra Pal Singh, Dehradun.

Kokate CK. (1997) Practical Pharmacognosy, pp.110111 Vallabh Prakashan, Delhi.

Lipschitz WL, Hadidian Z, Kerpesar A. (1943) Bioassay of diuretics. J. Pharmacol. Exp. Ther. 79, 97-110.

Leuschner J. (1995) Anti-inflammatory, spasmolytic and diuretic effects of a commercially available Solidago gigantea Herb Extract. Arzneim-Forsch. Drug Res. 45, 15-168.

Mamun MM, Billah MM, Ashek MA, Ahasan MM, Hossain MJ, Sultana T. (2003) Evaluation of diuretic activity of Ipomoea aquatica (Kalmisak) in mice model study. J. Med. Sci. 3, 395-400.

Milton JC, Sheldon M, Brainerd H. (1970) Handbook of Medical Treatment $12^{\text {th }}$ ed pp.220-229 Lange Publications, California.

Mukherjee PK, Pal M, Saha K, Saha BP. (1996) Diuretic activity of extract of the rhizomes of Nelumbo nucifera Gaertn. (Fam. Nymphaeaceae). Phytother. Res. 10, 424-425.

Mukherjee T. (1991) Antimalarial herbal drugs. A review. Fitoterapia 62, 197-204.

Murugesan T, Manikandan L, Suresh, KB, Pal M, Saha BP. (2000) Evaluation of diuretic potentials of J. suffruticosa Linn extracts in rats. Indian J. Pharm. Sci. 62, 150.

Nadkarni AK. (1954) Indian Materia Medica, pp. 746 Popular Prakashan, Bombay, India.

Nilveses N, Wammanachinda W, Wanverakul B, Pidech P. (1989) Diuretic effect of Pluchea indica. Thai journal of Pharmacology. 11, 1-7. 
OECD. (1996) OECD Guidelines for the testing of chemicals Test No 423: Acute oral toxicity- Acute toxic classic method.

Pantoja CV, Chiang LCH, Norris BC, Concha JB. (1991) Diuretic, natriuretic and hypotensive effects produced by Allium sativum (Garlic) in anesthetized dogs. J. Ethnopharmacol. 31, 325-331.

Ramachandra K. (1989) Useful Plants of India, pp. 246 Publications and Information Directorate, CSIR, New Delhi.

Rang HP, Dale MM, Ritter JM, Moore PK. (2003) Pharmacology, Fifth edition, pp. 352-366 Elsevier Science Limited, United Kingdom.

Rani A. (1988) Experimental evaluation of antilithiatic activity of Homonia repeoria lour in male albino rats [Dissertation] Mangalore University, Manipal.

Rizvi SH, Shoeb A, Kapil RS, Satya P. (1980) Two diuretic triterpenoids from Antiderma menasu. Phytochemistry 19, 2409-2410.

Sheth UK, Dadkar NK, Kamat UG. (1972) Selected Topics in Experimental Pharmacology. pp. 164-166 Kothari Book Depot, Bombay.

Singh RH, Udupa KN. (1972) Studies on the Indian indigenous drug, Punarnava (Boerhavvia diffusa Linn). J. Res. Indian Med. 7, 29-31.

Singh RG, Singh RP, Usha KP. (1991) Experimental evaluation of diuretic action of herbal drug (Tribulus terrestris Linn.) on albino rats. J. Res. Educ. Indian Med. 3, 19-21.

Somova LI, Shode FO, Ramanan P, Nadar A. (2003) Antihypertensive, antiatherosclerotic and antioxidant activity of triterpenoids isolated from Olea europaea, subspecies Africana leaves. J. Ethnopharmacol. 84, 299-305.

Sood AR, Bajpai A and Digits M. (1985) Pharmacological and biological studies on saponins. Indian J. Pharmacol. 17, 178-179.

Srivastava R, Shukla YN, Kumar S. (1988) Chemistry, Pharmacology and botany of Boerhavvia diffusa. J. Medicinal Aromatic Plant Sci. 20, 762-766.

Stanton BA, Giebisch GH. (1992) Renal potassium transport. In: Handbook of Physiology. Section 8: Renal Physiology edited by Windhager, E.E p. 813874 Oxford University Press, New York.

The Useful Plants of India. (1986) Third Edition, pp. 450 Publication \& Information Directorate, Council of Scientific \& Industrial Research, New Delhi.

Van Armar GG. (1954) The diuretic activity of isocytosines. J. Pharmacol. Exp. Ther. 111, 285-292.

Wealth of India-Raw materials. (1962) Vol VI, pp. 142143 Publication and Information Directorate, Council of Scientific and Industrial Research, New Delhi.

Wilson RW, Wareing M, Green R. (1997) The role of active transport in potassium reabsortption in the proximal convoluted tubule of the anesthetized rat. J. Physiol. 500, 155-164.

Zafar R. (1994) Medicinal Plants of India. $1^{\text {st }} \mathrm{Ed}$, pp. 361-362 CBS Publications, New Delhi.

Zamora-Martinez MC, Nieto de Pascual C. (1992) Medicinal plants used in some rural populations of Oaxaca, Publa and Veracruz, Mexico. J. Ethnopharmacol. 35, 229-257. 